\title{
HIPERVOLEMIA PADA PASIEN CONGESTIVE HEART FAILURE (CHF)
}

\author{
Yeni Eka Astuti, Yuyun Setyorini, Akhmad Rifai \\ Kementerian Kesehatan Politeknik Kesehatan Surakarta Jurusan Keperawatan \\ Diterima : 12 Oktober 2018, Disetujui : 26 Oktober 2018
}

\begin{abstract}
Background: Congestive Heart Failure (CHF) is a condition in which the heart is unable to pump blood normally, causing disturbed venous return pressure to cause edema. The problem that arises is hypervolemia or intracellular fluid resuscitation to the interstitial that causes edema so that can be arranged nursing intervention one of them is giving diuretic and monitor fluid balance. Describes nursing care performed in Congestive Heart Failure (CHF) patients with hypervolemia. Method: This study uses data analysis method that is conducting the nursing process of two patients Congestive Heart Failure (CHF) who suffered from Hypervolemia disorder and then compared with case study journal as well as other sources. Result: After nursing action in both patients the Hipervolemia problem is equally partially resolved by fluid restriction nursing interventions, and the administration of diuretics. Conclusion: In providing nursing care to patients with Congestive Heart Failure $(\mathrm{CHF})$ should pay attention to fluid restriction and appropriate diuretic administration to reduce edema.
\end{abstract}

Keyword: Congestive Heart Failure (CHF), Hipervolemia, Nursing Care

\section{PENDAHULUAN}

Menurut Alimul (2012) kebutuhan cairan adalah bagian dari kebutuhan dasar manusia yang memiliki proporsi besar dalam tubuh. Hidayat dan Uliyah (2015) menyebutkan bahwa pengaturan cairan dilakukan oleh mekanisme rasa haus, sistem hormonal yakni Anti Diuretik Hormon (ADH), sistem aldosteron, prostaglandin, dan glukokortikoid.

Cairan tubuh dapat berpindah dengan berbagai cara yaitu dengan difusi, osmosis, dan transpor aktif. Cara perpindahan yang pertama yaitu difusi yang berarti molekul berpindah dari konsentrasi yang tinggi ke rendah. Cara perpindahan cairan yang kedua yaitu osmosis yang berarti perpindahan zat dari larutan dengan konsentrasi kurang pekat ke larutan konsentrasi yang lebih pekat melalui membran semipermeable, sehingga volume cairan dengan konsentrasi kurang pekat akan berkurang dan volume cairan dengan konsentrasi lebih pekat akan bertambah. Cara perpindahan cairan yang terakhir yaitu transpor aktif berarti pergerakan cairan tubuh atau gerak zat yang akan berdifusi dan berosmosis (Hidayat \& Uliyah, 2015).

Hidayat dan Uliyah (2015) menyatakan bahwa kebutuhan cairan adalah kebutuhan dasar yang memiliki proporsi besar dalam tubuh. Kategori presentase cairan tubuh berdasarkan umur adalah bayi baru lahir $75 \%$ dari total berat badan, pria dewasa $57 \%$ dari total berat badan, wanita dewasa $55 \%$ dari total berat badan, dan dewasa tua $45 \%$ dari total berat badan.

Pengkajian yang dilakukan meliputi Pengkajian Kesadaran dengan 
menggunakan Glasgow Coma Scale (GCS), Pengkajian Primer meliputi

Airway, Breathing, Circulation, Dissability, ksposure dan Pengkajian Sekunder meliputi SAMPLE (Sign and Symptom, Allergies, Medications, Past Illnes, Last Meal, Event)

Pengkajian umum meliputi pengkajian riwayat keperawatan, pengkajian faktor yang berhubungan, pengkajian fisik sistem integumen meliputi inspeksi dengan melihat warna kulit, purpura/ptechiae pada sela jari, telapak tangan atau kaki, eritema, splinter hemorrhagic pada kuku, capillary refill time, clubbing finger, dan edema. Palpasi dilakukan pada pasien CHF dengan gangguan kebutuhan cairan yaitu pitting edema, suhu ekstremitas akibat penurunan aliran darah ke jaringan perifer, nyeri akibat tromboplebitis vena kaki, denyut nadi perifer. Hal yang perlu dikaji dalam denyut nadi perifer adalah keadaan pembuluh darah arteri, frekuensi, irama, ciri denyutan, dan isi nadi.

Pemeriksaan

Laboratorium dilakukan dengan pemeriksaan sistem hematologik, serum isoenzim kardiak, faal hemostasis, arterial blood gasses, tes fungsi ginjal, kimia darah, elektrolit, dan urine analisis.

Diagnosa yang muncul antara lain Hipervolemia. Intervensi pada kasus Hipervolemia antara lain ; 1) Observasi tanda-tanda edema; 2) Observasi pembesaran hati dan limfa; catat adanya mual, muntah, distensi, dan konstipasi; 3) Timbang berat badan setiap hari (jika kondisi memungkinkan); 4) Observasi input dan output cairan; 5) Anjurkan diet rendah garam dan batasi asupan cairan; 6) Kolaborasi tim medis untuk terapi dan tindakan pemberian diuretik. Intervensi untuk masalah Hipovolemia antara lain ; 1) Monitor status hidrasi (kelembaban membran mukosa, nadi adekuat); 2) Monitor berat badan; 3) Monitor intake dan output cairan; 4) Dorong klien menambah intake oral; 5) Kolaborasi pemberian cairan IV.

Menurut Debora

(2012), implementasi adalah tahap keempat dari proses keperawatan. Tahap ini muncul jika perencanaan yang dibuat diaplikasikan pada pasien. Tindakan yang dilakukan mungkin sama, mungkin juga berbeda dengan urutan yang telah dibuat pada perencanaan. Implementasi keperawatan membutuhkan fleksibilitas dan kreativitas perawat.

Evaluasi terhadap gangguan kebutuhan cairan dan elektrolit secara umum dapat dinilai dari adanya kemampuan dalam mempertahankan keseimbangan cairan dan elektrolit dengan ditunjukkan oleh adanya keseimbangan antara jumlah asupan dan pengeluaran, berat badan normal tidak ada penurunan dan peningkatan secara cepat, turgor kulit baik, tidak terjadi edema, dan lain sebagainya(Udjianti, 2013).

a. Pengertian CHF

Arif Muttaqin (2009) menyatakan bahwa gagal jantung adalah suatu keadaan ketika jantung tidak mampu mempertahankan sirkulasi yang cukup bagi tubuh, meskipun tekanan pengisian vena normal.

\section{b. Patofisiologi}

Aspiani (2015) menjelaskan bahwa kelainan intrinsik pada kontraktilitas miokard yang khas pada gagal jantung akibat penyakit jantung iskemik, menggangu kemampuan pengosongan ventrikel yang efektif.Kontraktilitas ventrikel kiri yang menurun mengurangi 
curah sekuncup, dan meningkatkan volume residu ventrikel. Sebagai respon terhadap gagal jantung, terdapat tiga mekanisme primer yang dapat dilihat yaitu: meningkatnya aktivitas adrenergik simpatik, meningkatnya beban awal akibat aktivasi sistem renin angiotensin aldosteron, dan hipertrofi ventrikel.

Aspiani (2015) menjelaskan bahwa ketiga respon kompensatorik ini mencerminkan usaha untuk mempertahankan curah jantung.Kelainan pada ventrikel dan menurunnya curah jantung biasanya tampak pada keadaan beraktivitas. Dengan berlanjutnya gagal jantung maka kompensasi akan semakin kurang efektif. Menurunnya curah sekuncup pada gagal jantung akan membangkitkan respon simpatik kompensatorik. Meningkatnya aktivitas adrenergik simpatik akan merangsang pengeluaran katekolamin dari saraf adrenergik jantung dan medula adrenal. Denyut jantung dan kekuatan kontraksi akan meningkat untuk menambah curah jantung. Juga terjadi kontriksi arteri perifer untuk menstabilkan tekanan arteri dan redistribusi volume darah dengan mengurangi aliran darah ke organ yang rendah metabolismenya, seperti kulit dan ginjal, agar perfusi ke jantung dan otak dapat dipertahankan. Penurunan curah jantung pada gagal jantung akan memulai serangkaian peristiwa antara lain :

1. Penurunan aliran darah ginjal dan akhirnya laju filtrasi glomerulus menurun

2. Pelepasan renin dari aparatus juksta glomerulus

3. Interaksi renin dengan angiotensinogen dalam darah untuk menghasilkan angiotensin I

4. Konversi angiotensin I menjadi angiotensin II
5. Merangsang sekresi aldosteron dari kalenjar adrenal

6. Retensi natrium dan air pada tubulus distal dan duktus pengumpul

Respon kompensatorik terakhir dari gagal jantung adalah hipertrofi miokardium atau bertambah tebalnya dinding jantung.Hipertrofi meningkatkan jumlah sarkomer pada sel-sel miokardium, tergantung dari jenis beban yang mengakibatkan gagal jantung.Sarkomer dapat bertambah secara paralel atau serial.Respons miokardium terhadap beban volume seperti regurgitasi aorta ditandai dengan dilatasi dan bertambahnya tebal dinding.

Aspiani (2015) menjelaskan lebih lanjut bahwa gagal jantung dapat terjadi pada bagian kanan (gagal jantung kanan) dan kiri (gagal jantung kiri).Pada gagal jantung kanan dikarenakan ketidakmampuan kanan yang mengakibatkan penimbunan darah dalam atrium kanan, vena kava dan sirkulasi besar.Penimbunan darah di vena hepatika menyebabkan hepatomegali dan kemudian menyebabkan asites. Pada ginjal akan menyebabkan penimbunan air dan natrium sehingga terjadi edema. Penimbunan secara sistemik selain menimbulkan edema juga meningkatkan tekanan vena jugularis dan pelebaran vena-vena lainnya.Pada gagal jantung kiri darah dari atrium kiri ke ventrikel kiri mengalami hambatan, sehingga atrium kiri dilatasi dan hipertrofi.Aliran darah paru ke atrium kiri terbendung.Akibatnya tekanan dalam vena pulmonalis, kapiler paru dan arteri pulmonalis meninggi. Bendungan terjadi juga di paru yang akan mengakibatkan edema paru, sesak saat bekerja (dypnea d'effort), atau waktu istirahat (ortopnea).

Aspiani (2015) menjelaskan bahwa gagal jantung kanan dan kiri terjadi 
sebagai akibat kelanjutan dari gagal jantung kiri.Setelah terjadi hipertensi pulmonal terjadi penimbunan darah dalam ventrikel kanan, selanjutnya terjadi gagal jantung kanan. Setiap penyumbatan pada aliran darah (forward flow) pada sirkulasi akan menimbulkan bendungan pada arah berlawanan dengan aliran (backward congestion). Hambatan pengaliran (forward failure)akan menimbulkan adanya gejala backward failure dalam sistem sirkulasi aliran darah. Mekanisme kompensasi jantung pada kegagalan jantung adalah upaya tubuh dalam mempertahankan peredaran darah dalam memenuhi kebutuhan metabolisme jaringan. Mekanisme kompensasi yang terjadi pada gagal jantung adalah dilatasi ventrikel, hipertrofi ventrikel, kenaikan rangsang simpatis berupa takikardi dan vasokonstriksi perifer, peninggian kadar katekolamin plasma, retensi garam dan cairan badan, serta peningkatan ekstraksi oksigen oleh jaringan. Bila jantung bagian kanan dan kiri bersama- sama gagal akibat gangguan aliran darah dan adanya bendungan, maka akan tampak tanda dan gejala gagal jantung pada sirkulasi sistemik dan sirkulasi paru. Keadaan ini disebut gagal jantung kongestif.

\section{METODE PENELITIAN}

Jenis penelitian yang digunakan adalah penelitian deskriptif. Penilitian deskriptif dimaksudkan untuk mendiskripsikan secara sistematis dan akurat suatu situasi atau area populasi tertentu yang bersifat faktual. Penelitian deskriptif bertujuan untuk memaparkan peristiwa- peristiwa penting yang terjadi pada masa kini. Hasil penelitian deskriptif sering digunakan atau dilanjutkan dengan penelitian analitik (Nursalam, 2013).

Rancangan penelitian yang digunakan adalah rancangan penelitian studi kasus. Penilitian studi kasus merupakan rancangan penelitian yang mencakup pengkajian satu unit penelitian secara intensif misalnya satu klien, keluarga, kelompok, komunitas, atau institusi. Meskipun jumlah subjek cenderung sedikit, namun jumlah variabel yang diteliti sangatlah luas (Nursalam, 2013).

Jenis penelitian yang digunakan dalam penyusunan karya tulis ilmiah ini adalah jenis penelitian deskriptif dan rancangan studi kasus dengan pendekatan asuhan keperawatan yang meliputi: pengkajian, diagnosa keperawatan, intervensi keperawatan, implementasi keperawatan, dan evaluasi keperawatan.

Subjek dalam studi kasus ini menggunakan dua klien kelolaan yang diamati secara mendalam. Subjek yang diobservasi adalah pasien Congestive Heart Failure (CHF) dengan masalah hipervolemia.

Peneliti menggunakan teknik pengumpulan data :

1. Observasi (pengamatan)

Observasi merupakan cara pengumpulan data dengan mengadakan pengamatan secara langsung kepada responden untuk mencari perubahan atau hal-hal yang akan diteliti. Dalam metode observasi ini, instrumen yang dapat digunakan antara lain : lembar observasi, panduan pengamatan (observasi) atau lembar checklist (Hidayat, 2014).

Dalam pengumpulan data ini penulis mengobservasi berat badan pasien, elastisitas kulit, vital sign, intake dan output cairan, serta 
observasi respon pasien setelah dilakukan tindakan keperawatan.

2. Wawancara

Menurut Nursalam wawancara adalah suatu metode yang digunakan untuk mengumpulkan data, dimana peneliti mendapatkan keterangan secara lisan dari seseorang sasaran penelitian (responden) atau bercakap-cakap berhadapan muka dengan orang tersebut (face to face).Wawancara yang digunakan yaitu wawancara autoanamnesa untuk mendapatkan informasi riwayat kesehatan dahulu, keluarga, dan saat ini.

3. Studi Dokumentasi

Dokumentasi merupakan metode pengumpulan data dengan cara mengambil data yang berasal dari dokumentasi asli. Dokumen asli tersebut dapat berupa gambar, table atau daftar periksa (Hidayat, 2014).

Peneliti mengumpulkan data dari hasil catatan keperawatan, catatan medis, dan hasil pemeriksaan darah

1. Analisa Data

Penulis melakukan analisis data dengan cara deskriptif. Menurut Nursalam (2016) analisa data dengan cara deskriptif adalah suatu metode yang dilakukan dengan tujuan utama untuk memaparkan atau memberi gambaran tentang studi keadaan secara obyektif yang dilakukan dengan mengobservasi keadaan klien. Analisa data dilakukan dengan pendekatan asuhan keperawatan yaitu dengan pengkajian, merumuskan diagnose keperawatan, menyusun perencanaan dan tindakan keperawatan, serta evaluasi keperawatan. Metode yang dilakukan yaitu dengan membandingkan kriteria hasil yaitu edema hilang atau tidak, balance cairan normal atau tidak, berat badan ideal, dan hati dan limfa normal atau terjadi pembesaran antara 2 klien kelolaan $\mathrm{CHF}$ yang mengalami masalah hipervolemia dengan jurnal, buku, dan lain-lain.

\section{HASIL PENELITIAN}

1. Pasien I

\section{A. Pengkajian}

Pengkajian dilakukan pada hari kamis 8 Maret 2018 dengan metode wawancara, observasi, dan cartatan medis.

1. Identitas pasien

$\begin{array}{ll}\text { Nama } & \text { : Ny.R } \\ \text { Umur } & : \text { 65 tahun } \\ \text { Alamat } & \text { : Klaten } \\ \text { Jenis kelamin } & \text { : Perempuan } \\ \text { Agama } & : \text { Islam } \\ \text { Diagnosa medis } & \text { : CHF } \\ \text { 2. Identitas penanggung jawab } \\ \text { Nama } & : \text { Ny. S } \\ \text { Umur } & : 39 \text { tahun } \\ \text { Alamat } & : \text { Klaten }\end{array}$

Hubungan dengan pasien : Anak

3. Pengkajian primer

a) Airway : Jalan nafas paten

b) Breathing $: \mathrm{RR}=28 \mathrm{x} / \mathrm{menit}$, pengembangan dada simetris, suara nafas ronkhi di basal paru kanan dan kiri

c) Circulation : $\mathrm{HR}=108 \mathrm{x} /$ menit, CRT < 2 detik, akral teraba hangat, kering, merah, tekanan darah 106/68 $\mathrm{mmHg}$

d) Dissability : $\quad$ Kesadaran composmentis, GCS E4 V5 M6

e) Eksposure : Terdapat pitting edema di kedua kaki kedalaman 2 mm waktu kembali 3 detik dan kekuatan otot 5 , tidak terdapat luka 
4. Pengkajian sekunder

a) Symptoms : Sesak nafas, pitting edema di kedua kaki kedalaman $2 \mathrm{~mm}$ waktu kembali 3 detik

b) Allergies : Pasien mengatakan tidak memiliki riwayat alergi baik obat ataupun makanan

c) Medication : keluarga pasien mengatakan pasien rutin mengkonsumsi obat jantung dan diabetes

d) Past illnes : Keluarga pasien mengatakan pasien memiliki penyakit diabetes mellitus sejak 5 tahun lalu dan penyakit jantung sejak 1 tahun yang lalu

e) Last meal : : Pasien mengatakan terakhir makan pukul 12.00 WIB habis setengah porsi

f) Event : Pasien mengatakan sesak nafas sejak 2 hari sebelum masuk Rumah Sakit dan kaki bengkak sejak 5 hari sebelum masuk Rumah Sakit, sesak nafas memberat saat aktivitas.

5. Pengkajian cairan

Berat badan pasien : $46 \mathrm{~kg}$

a) Input

Makan dan minum : $500 \mathrm{cc} / 10$ jam

Parenteral : $220 \mathrm{cc} / 10$

jam

Total input $\quad: 720 \mathrm{cc} / 10$

jam

b) Output

Urine $\quad: 200 \mathrm{cc} / 10 \mathrm{jam}$

IWL $\quad: 288 \mathrm{cc} / 10 \mathrm{jam}$

Total output : $488 \mathrm{cc} / 10 \mathrm{jam}$

c) Balance cairan

$\mathrm{BC}=\mathrm{CM}-\mathrm{CK}-\mathrm{IWL}$

$=720-200-288$

$=+232 / 10 \mathrm{jam}$
6. Pemeriksaan fisik

a) Inspeksi : Warna kulit sawo matang, tidak ada eritema, CRT $<2$ detik, terdapat edema di kedua kaki

b) Palpasi : Terdapat pitting edema di kedua kaki kedalaman $2 \mathrm{~mm}$ waktu kembali 3 detik

7. Program terapi

Parenteral : infus $\mathrm{NaCl} 9 \% \quad 500$

cc/24 jam Furosemide 40

$\mathrm{mg} / 8$ jam Per Oral : Candesartan $8 \mathrm{mg}$ $(1-0-0)$ Clopidogrel $75 \mathrm{mg} / 24 \mathrm{jam}$ Cefoperazone $1 \mathrm{gr} / 12 \mathrm{jam}$

8. Pemeriksaan penunjang

Pemeriksaan Foto Thorax

Hasil :

Cardiomegali dengan arteriosclerosis

Pulmonary edema, Efusi Pleura (+) dextra/ sinistra, Osteoporosis

Tabel.1 Pemeriksaan dilakukan pada tanggal 8 maret 2018

\begin{tabular}{|c|c|c|c|}
\hline Pemeriksaan & Hasil & Satuan & $\begin{array}{c}\text { Nilai } \\
\text { Rujukan }\end{array}$ \\
\hline \multicolumn{4}{|l|}{ Darah Rutin } \\
\hline Hemoglobin & 12,0 & $\mathrm{~g} / \mathrm{dL}$ & $12,0-16,0$ \\
\hline Eritrosit & 3,94 & juta/uL & $4,20-5,50$ \\
\hline Lekosit & 22,8 & ribu/ul & $4,8-10,8$ \\
\hline Trombosit & 177 & ribu/ul & $150-450$ \\
\hline Hematokrit & 35,3 & $\%$ & $37,0-52,0$ \\
\hline MCV & 89,6 & $\mathrm{fL}$ & $80,0-99,0$ \\
\hline $\mathrm{MCH}$ & 30,5 & $\mathrm{fL}$ & $27-31$ \\
\hline $\mathrm{MCHC}$ & 34,0 & $\mathrm{~g} / \mathrm{dL}$ & $33,0-37,0$ \\
\hline RDW & 13,9 & $\%$ & $10,0-15,0$ \\
\hline MPV & 8,6 & $\mathrm{fL}$ & \\
\hline \multicolumn{4}{|l|}{ Kimia Klinik } \\
\hline Total protein & 6,41 & $\mathrm{~g} / \mathrm{dL}$ & \\
\hline Albumin & 3,1 & $\mathrm{~g} / \mathrm{dL}$ & $6,60-8,80$ \\
\hline Globulin & 3,3 & $\mathrm{~g} / \mathrm{dL}$ & $3,5-5,0$ \\
\hline Ureum & 223,6 & $\mathrm{mg} / \mathrm{dL}$ & $2,9-3,3$ \\
\hline Creatinin & 2,62 & $\mathrm{mg} / \mathrm{dL}$ & $15,0-40,0$ \\
\hline BUN & 104,5 & $\mathrm{mg} / \mathrm{dL}$ & $0,6-0,9$ \\
\hline Elektrolit & & & $7,0-18,0$ \\
\hline Natrium & 135,6 & $\mathrm{mmol} / \mathrm{L}$ & \\
\hline Kalium & 4,26 & $\mathrm{mmol} / \mathrm{L}$ & \\
\hline Chlorida & 105,9 & $\mathrm{mmol} / \mathrm{L}$ & $\begin{array}{c}136,0-145 \\
3,5-5,1 \\
98,0- \\
107,0\end{array}$ \\
\hline
\end{tabular}


9. Analisa data

Tabel 2. Analisis Data

\begin{tabular}{|c|c|c|c|}
\hline \multicolumn{2}{|r|}{ Data Fokus } & Problem & Etiologi \\
\hline \multicolumn{2}{|c|}{$\begin{array}{l}\text { Pasien } \\
\text { mengatakan }\end{array}$} & Hipervolemia & $\begin{array}{l}\text { Gangguan } \\
\text { aliran balik }\end{array}$ \\
\hline \multicolumn{2}{|c|}{$\begin{array}{l}\text { kedua } \\
\text { bengkak }\end{array} \quad$ kaki } & & \\
\hline \multicolumn{2}{|c|}{$\mathrm{DO}:$} & & \\
\hline a) & \begin{tabular}{l}
\multicolumn{2}{l}{ Terdapat } \\
pitting \\
pada dema \\
kaki
\end{tabular} & & \\
\hline b) & $\begin{array}{l}\text { Terdapat } \\
\text { cardiomegali } \\
\text { dan pulmonary } \\
\text { edema }\end{array}$ & & \\
\hline c) & Sesak nafas & & \\
\hline
\end{tabular}

B. Diagnosa

Hipervolemia berhubungan dengan gangguan aliran balik vena

C. Intervensi

Tabel 3. Intervensi

\begin{tabular}{|c|c|c|}
\hline Diagnosa & $\begin{array}{c}\text { Tujuan dan } \\
\text { Kriteria Hasil }\end{array}$ & Intervensi \\
\hline $\begin{array}{l}\text { Hipervolemia } \\
\text { berhubungan } \\
\text { dengan } \\
\text { gangguan } \\
\text { aliran balik } \\
\text { vena }\end{array}$ & $\begin{array}{l}\text { Setelah } \\
\text { dilakukan } \\
\text { tindakan } \\
\text { keperawatan } \\
\text { selama 2x24 } \\
\text { jam masalah } \\
\text { hipervolemia } \\
\text { teratasi } \\
\text { dengan } \\
\text { kriteria hasil: } \\
\text { 1. } \\
\text { Edema } \\
\text { hilang } \\
\text { 2. } \begin{array}{l}\text { Balance } \\
\text { cairan }\end{array} \\
\text { seimbang } \\
\text { 3. Tidak } \\
\text { terjadi } \\
\text { pembesar } \\
\text { an hati } \\
\text { 4. Sesak } \\
\text { nafas } \\
\text { berkuran } \\
\text { g }\end{array}$ & 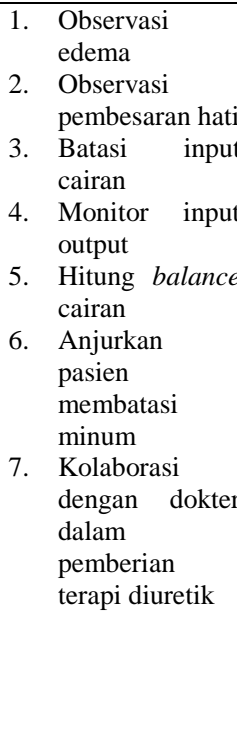 \\
\hline
\end{tabular}

D. Implementasi

Berdasarkan intervensi keperawatan yang telah disusun pada hari kamis tanggal 8 Maret 2018 dapat dilakukan tindakan keperawatan pada Ny. R dengan Congestive Heart Failure (CHF) yaitu:

\section{Hari pertama}

Implementasi hari pertama pada tanggal 8 Maret 2018 pukul 17.00 WIB sampai tanggal 9 Maret 2018 pukul 17.00 WIB mengobservasi edema dengan hasil terjadi pitting edema pada ekstremitas bawah kedalaman $2 \mathrm{~mm}$ kembali dalam waktu 3 detik, pukul 17.10 WIB menganjurkan membatasi minum, 18.00 WIB memonitor input dan output dengan hasil input : $740 \mathrm{cc} / 11$ jam, output : 526 cc/11 jam, 18.10 WIB menghitung balance cairan didapatkan hasil : +214 cc/11 jam, dilakukan evaluasi pada hari Jum'at 9 Maret 2018 pukul 17.00 WIB dengan dengan hasil input : $1212 \mathrm{cc} / 24$ jam, output : $1090 \mathrm{cc} / 24$ jam, kemudian menghitung balance cairan didapatkan hasil : $+132 \mathrm{cc} / 24$ jam

2. Hari kedua

Implementasi hari kedua pada tanggal 9 Maret 2018 pukul 16.00 WIB mengobservasi edema dengan hasil pitting edema pada ekstremitas bawah dengan kedealaman $2 \mathrm{~mm}$ kembali selama 2 detik, 16.30 WIB menganjurkan pasien membatasi minumnya, 17.00 WIB memonitor input dan output dengan hasil input : $1162 \mathrm{cc} / 24$ jam output : $1140 \mathrm{cc} / 24$ jam, 17.10 WIB menghitung balance cairan didapatkan hasil : $+22 \mathrm{cc} / 24$ jam

E. Evaluasi

Evaluasi Ny. R dilakukan pada hari sabtu tanggal 10 Maret 2018 pukul 20.00 WIB didapatkan data subyektif pasien mengatakan bengkak di kaki berkurang dibandingkan hari kemarin, data obyektif ditemukan pitting edema kedalaman $2 \mathrm{~mm}$ kembali semula selama 2 detik, input dan output dengan hasil input makan dan minum : $650 \mathrm{cc} / 24$ jam, parenteral : 512 $\mathrm{cc} / 24 \mathrm{jam}$, total input : $1162 \mathrm{cc} / 24 \mathrm{jam}$, output urin : $450 \mathrm{cc} / 24$ jam IWL : 690 $\mathrm{cc} / 24 \mathrm{jam}$, total output : $1140 \mathrm{cc} / 24 \mathrm{jam}$, balance cairan : $+22 \mathrm{cc} / 24 \mathrm{jam}$, hasil assesment masalah hipervolemia teratasi sebagian dan untuk planning dilanjutkan 
intervensinya mencakup observasi edema, observasi adanya pembesaran jantung, monitor input dan output cairan, anjurkan klien membatasi asupan cairan, kolaborasi dengan dokter dalam pemberian terapi diuretik.

\section{Pasien II}

\section{A. Pengkajian}

Pengkajian dilakukan pada hari Jum'at 30 Maret 2018 dengan metode wawancara, observasi, dan catatan medis.

1. Identitas pasien

$\begin{array}{ll}\text { Nama } & : \text { Ny.A } \\ \text { Umur } & : 67 \text { tahun }\end{array}$

$\begin{array}{lr}\text { Alamat } & \text { : Klaten } \\ \text { Jenis kelamin } & \text { : }\end{array}$

Perempuan

Agama : Islam

Diagnosa medis : CHF, STEMI

2. Identitas penanggung jawab

$\begin{array}{ll}\text { Nama } & : \text { Tn. D } \\ \text { Umur } & : 34 \text { tahun }\end{array}$

Alamat : Klaten

Hubungan dengan pasien : Anak

3. Pengkajian primer

a) Airway : Jalan nafas paten

b) Breathing : $\mathrm{RR}=26$

$\mathrm{x} /$ menit, pengembangan dada simetris, suara nafas vesikuler di seluru lapang paru

c) Circulation : $\mathrm{HR}=74 \mathrm{x} / \mathrm{menit}$, CRT < 2 detik, akral teraba hangat, kering, merah

d) Dissability : $\quad$ Kesadaran composmentis, GCS E4 V5 M6

e) Eksposure : Terdapat edema non pitting di kedua kaki dan kekuatan otot 5, tidak terdapat trauma

4. Pengkajian sekunder
a) Symptoms
Sesak
nafas, edema non pitting di kedua kaki

b) Allergies : Pasien mengatakan tidak memiliki riwayat alergi baik obat ataupun makanan

c) Medication : Keluarga pasien mengatakan pasien rutin minum obat jantung tetapi keluarga pasien tidak tahu nama obat yang dikonsumsi karena tidak membawa obat pasien

d) Past illnes : Keluarga pasien mengatakan pasien pernah dirawat dengan penyakit yang sama dan melakukan kontrol rutin setiap bulan

e) Last meal : Pasien mengatakan terakhir makan pukul 17.00 WIB habis setengah porsi

f) Event : Pasien mengatakan gejala memberat saat beraktivitas.

5. Pengkajian cairan

Berat badan pasien : $50 \mathrm{~kg}$

a) Input

Makan dan minum : $550 \mathrm{cc} / 10 \mathrm{jam}$

Parenteral $: 300 \mathrm{cc} / 10 \mathrm{jam}$

Total input $: 850 \mathrm{cc} / 10 \mathrm{jam}$

b) Output

Urine $\quad: 450 \mathrm{cc} / 10 \mathrm{jam}$

IWL $: 312 \mathrm{cc} / 10 \mathrm{jam}$

Total output : $762 \mathrm{cc} / 10 \mathrm{jam}$

c) Balance cairan

$\mathrm{BC}=\mathrm{CM}-\mathrm{CK}-\mathrm{IWL}$

$$
\begin{aligned}
& =850-450-312 \\
& =+88 / 10 \mathrm{jam}
\end{aligned}
$$

6. Pemeriksaan fisik
a) Inspeksi : Warna kulit sawo matang, tidak ada eritema, CRT $<2$ detik, terdapat edema di kedua kaki
b) Palpasi : Terdapat edema non pitting di kedua kaki

7. Program terapi

Parenteral : Arixtra $\quad 2,5 \quad \mathrm{mg} / 24$ jam 
Per Oral : Clopidogrel $75 \mathrm{mg} / 24$ jam, Aspilet $80 \mathrm{mg} / 24$ jam, Atorvastatin $\quad 40 \mathrm{mg} / 24 \mathrm{jam}$

8. Pemeriksaan penunjang Pemeriksaan Ekokardiografi

Hasil :

LA LV RV dilatasi, LVH eksentrik, Fungsi sistolik global turun dengan EF $32 \%$, Gangguan kinetik segmental, Disungsi diastolik LV tipe relaksasi, Fungsi sistolik RV normal, MR mild, AR moderate, TR mild

Tabel 4. Pemeriksaan dilakukan pada tanggal 29 maret 2018

\begin{tabular}{|c|c|c|c|}
\hline Pemeriksaan & Hasil & Satuan & $\begin{array}{c}\text { Nilai } \\
\text { Rujukan }\end{array}$ \\
\hline \multicolumn{4}{|l|}{ Darah rutin } \\
\hline Hemoglo & 11,6 & $\mathrm{G} / \mathrm{dl}$ & $12,0-$ \\
\hline bin & 3,74 & Juta/ul & 16,0 \\
\hline Eritrosit & 14,2 & Ribu/ul & $4,20-$ \\
\hline Lekosit & 465 & Ribu/ul & 5,50 \\
\hline Trombosi & 35,6 & $\%$ & $4,8-$ \\
\hline $\mathrm{t}$ & 95,1 & $\mathrm{Fl}$ & 10,8 \\
\hline Hematok & 31,0 & $\mathrm{Fl}$ & $150-$ \\
\hline rit & 32,5 & $\mathrm{G} / \mathrm{dl}$ & 450 \\
\hline $\mathrm{Mcv}$ & 14,9 & $\%$ & $37,0-$ \\
\hline Mch & 8,7 & $\mathrm{Fl}$ & 52,0 \\
\hline Mchc & & & $80,0-$ \\
\hline Rdw & & & 99,0 \\
\hline \multirow[t]{2}{*}{$\mathrm{Mpv}$} & 68,5 & $\mathrm{Mg} / \mathrm{dl}$ & $27-31$ \\
\hline & 1,68 & $\mathrm{Mg} / \mathrm{dl}$ & $33,0-$ \\
\hline Kimia klinik & 32,0 & $\mathrm{Mg} / \mathrm{dl}$ & 37,0 \\
\hline Ureum & & & $10,0-$ \\
\hline Creatinin & & & 15,0 \\
\hline \multirow[t]{2}{*}{ Bun } & 141,9 & $\mathrm{Mmol} / \mathrm{l}$ & \\
\hline & 4,01 & $\mathrm{Mmol} / \mathrm{l}$ & \\
\hline Elektrolit & 109,2 & $\mathrm{Mmol} / \mathrm{l}$ & \\
\hline Natrium & & & $15,0-$ \\
\hline Kalium & & & 40,0 \\
\hline \multirow[t]{8}{*}{ Chlorida } & & & $0,6-0,9$ \\
\hline & & & $7,0-$ \\
\hline & & & 18,0 \\
\hline & & & $136,0-$ \\
\hline & & & 145 \\
\hline & & & $3,5-5,1$ \\
\hline & & & $98,0-$ \\
\hline & & & 107,0 \\
\hline
\end{tabular}

9. Analisa data

Tabel 5. Analisis data

\begin{tabular}{|c|c|c|}
\hline Data Fokus & Problem & Etiologi \\
\hline $\begin{array}{l}\text { DS : } \\
\text { Pasien } \quad \text { mengatakan } \\
\text { kedua kaki bengkak }\end{array}$ & Hipervolemia & $\begin{array}{l}\text { Gangguan } \\
\text { aliran balik } \\
\text { vena }\end{array}$ \\
\hline $\begin{array}{l}\text { DO : } \\
\text { a) Terdapat } \\
\text { edema non pitting pada } \\
\text { kedua kaki }\end{array}$ & & \\
\hline 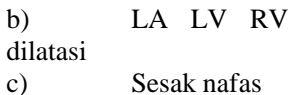 & & \\
\hline
\end{tabular}

c) Sesak nafas

B. Diagnosa

Hipervolemia berhubungan dengan gangguan aliran balik vena.

\section{Intervensi}

\begin{tabular}{|c|c|c|}
\hline Diagnosa & $\begin{array}{l}\text { Tujuan dan } \\
\text { Kriteria Hasil }\end{array}$ & Intervensi \\
\hline \multirow{16}{*}{$\begin{array}{l}\text { Hipervolemia } \\
\text { berhubungan } \\
\text { dengan gangguan } \\
\text { aliran balik vena }\end{array}$} & Setelah dilakukan & 1. Obser \\
\hline & tindakan & vasi edema \\
\hline & keperawatan & 2. Obser \\
\hline & $\begin{array}{l}\text { selama } 2 \times 24 \text { jam } \\
\text { masalah }\end{array}$ & $\begin{array}{l}\text { vasi pembesaran } \\
\text { hati }\end{array}$ \\
\hline & hipervolemia & Batasi \\
\hline & teratasi dengan & input cairan \\
\hline & kriteria hasil: & 4. Monit \\
\hline & 1. Edem & or input output \\
\hline & a hilang & 5. Hitung \\
\hline & Balan & balance cairan \\
\hline & cairan & 6. Anjurk \\
\hline & seimbang & an pasien \\
\hline & $\begin{array}{ll}3 . & \text { Tidak } \\
\text { terjadi } & \end{array}$ & $\begin{array}{l}\text { membatasi } \\
\text { minum }\end{array}$ \\
\hline & pembesaran hati & Kolab \\
\hline & 4. $\quad \mathrm{RR}=$ & orasi dengan \\
\hline & $16-20 \mathrm{x} / \mathrm{menit}$ & $\begin{array}{ll}\text { dokter } & \text { dalam } \\
\text { pemberian } & \text { terapi } \\
\text { diuretik } & \end{array}$ \\
\hline
\end{tabular}

\section{Implementasi}

Berdasarkan intervensi keperawatan yang telah disusun pada hari Jum'at tanggal 30 Maret 2018 dapat dilakukan tindakan keperawatan pada $\mathrm{Ny}$. A dengan Congestive Heart Failure(CHF) yaitu:

1. Hari pertama

Implementasi hari pertama pada tanggal 30 Maret 2018 pukul 20.00 WIB sampai Sabtu 31 Maret 2018 pukul 20.00 WIB. Pukul 20.10 WIB mengobservasi edema dengan hasil terjadi edema non pitting pada ekstremitas bawah, pukul 21.00 WIB memonitor input dan output. Evaluasi pada implementasi pertama 
didapatkan hasil input makan dan minum : $750 \mathrm{cc} / 24$ jam, parenteral : $720 \mathrm{cc} / 24$ jam, total input : $1470 \mathrm{cc} / 24$ jam, output urin dan feses : $550 \mathrm{cc} / 24$ jam dengan feses kurang lebih $100 \mathrm{cc}$, IWL : 750 cc/24 jam dan balance cairan : $1474-$ $1300=+174 \mathrm{cc} / 24 \mathrm{jam}$.

2. Hari kedua

Implementasi hari kedua pada tanggal 31 Maret 2018 pukul 20.00 WIB sampai Minggu 1 April 2018 pukul 20.00 WIB. Pukul 20.10 WIB mengobservasi edema dengan hasil edema non pitting pada ekstremitas bawah berkurang, 20.15 WIB monitor input dan output. Pukul 20.30 WIB menganjurkan pasien untuk membatasi minum. Dilakukan evaluasi pada tanggal 1 April 2018 pukul 20.00 WIB dengan hasil input makan dan minum : $800 \mathrm{cc} / 24$ jam, parenteral : 732 $\mathrm{cc} / 24 \mathrm{jam}$, total input : $1532 \mathrm{cc} / 24 \mathrm{jam}$ output urin : $750 \mathrm{cc} / 24$ jam, IWL : 750 $\mathrm{cc} / 24$ jam total output : $1500 \mathrm{cc} / 24$ jam, 20.20 WIB menghitung balance cairan didapatkan hasil : $+32 \mathrm{cc} / 24$ jam.

\section{E. Evaluasi}

Evaluasi Ny. A dilakukan pada hari jum'at tanggal 1 April 2018 pukul 20.00 WIB didapatkan data subyektif pasien mengatakan bengkak di kaki berkurang dibandingkan hari kemarin, data obyektif ditemukan edema non pitting berkurang, input makan dan minum : $800 \mathrm{cc} / 24 \mathrm{jam}$, parenteral : $732 \mathrm{cc} / 24 \mathrm{jam}$, total input : $1532 \mathrm{cc} / 24$ jam output urin : $750 \mathrm{cc} / 24$ jam, IWL : $750 \mathrm{cc} / 24$ jam total output : $1500 \mathrm{cc} / 24$ jam, balance cairan : +32 $\mathrm{cc} / 24$ jam, terdapat pembesaran jantung atau cardiomegali, hasil assesment masalah hipervolemia belum teratasi dan untuk planning dilanjutkan intervensinya mencakup observasi edema, observasi adanya pembesaran jantung, monitor input dan output cairan, anjurkan klien membatasi asupan cairan, kolaborasi dengan dokter dalam pemberian terapi diuretik.

\section{PEMBAHASAN}

Pada pembahasan ini penulis akan membahas tentang "Asuhan Keperawatan Pada Pasien Congestive Heart Failure (CHF) dengan Hipervolemia". Prinsip dari pembahasan ini dengan memfokuskan perubahan keseimbangan cairan yang terjadi pada pasien dengan Congestive Heart Failure (CHF).

Pada sub bab ini juga akan dijelaskan mengenai persamaan dan perbedaan hasil temuan pada pasien kasus pertama dan kasus kedua yang dikelola mulai dari pengkajian, diagnosa keperawatan, intervensi keperawatan, implementasi keperawatan, evaluasi keperawatan.

Pada pengkajian ditemukan perbedaan umur 2 tahun antara Ny. R dengan Ny. A. saat pengkajian juga didapatkan perbedaan edema yang terjadi pada $\mathrm{Ny}$. R yaitu pitting edema di ekstremitas bawah dengan kedalaman $2 \mathrm{~mm}$ waktu kembali 3 detik, tetapi pada Ny. A ditemukan edema pada ekstremitas bawah dengan waktu kembali 1 detik, hal ini terjadi karena balance cairan kedua pasien yang berbeda yaitu Ny. R balance cairan +232 sedangkan Ny. A balance cairan +88 . Pemeriksaan laboratorium pada Ny. R dan Ny. A didapatkan hasil :

Tabel 6. Pemeriksaan Laboratorium

\begin{tabular}{lcc}
\hline $\begin{array}{l}\text { Pemeriksaan } \\
\text { laboratorium }\end{array}$ & $\mathbf{N y} \cdot \mathbf{R}$ & $\mathbf{N y} \cdot \mathbf{A}$ \\
\hline Ureum & $223,6 \mathrm{mg} / \mathrm{dl}$ & $68,5 \mathrm{mg} / \mathrm{dl}$ \\
Kreatinin & $2,62 \mathrm{mg} / \mathrm{dl}$ & $1,68 \mathrm{mg} / \mathrm{dl}$ \\
Bun & $104,5 \mathrm{mg} / \mathrm{dl}$ & $32,0 \mathrm{mg} / \mathrm{dl}$ \\
\hline \multicolumn{1}{c}{ Pada pemeriksaan ini ditemukan } \\
penurunan fungsi ginjal, hal tersebut \\
menunjukkan bahwa CHF berpengaruh
\end{tabular}


pada fungsi ginjal. Rully (2009) mengungkapkan dalam tulisannya yang berjudul Sindroma Kardio Renal bahwa faktor yang menyebabkan terjadinya perburukan ginjal pada pasien CHF yaitu penurunan curah jantung akibat penurunan ejection fraction. Sindrome kardio renal ini ditandai dengan usia yang relatif tua, ejection fraction rendah, tekanan sistolik darah rendah. Pada kedua pasien yang dilakukan penelitian dapat disimpulkan bahwa keduanya mengalami sindrome kardio renal.

Diagnosa yang ditegakkan dalam penelitian ini diperoleh data yang sama yaitu hipervolemia. Intervensi yang dilakukan pada $\mathrm{Ny}$. R dan Ny. A sama dan implementasi yang dilakukan terjadi perbedaan yaitu pada Ny. R menggunakan diuretik Furosemide 40 $\mathrm{mg} / 8$ jam tetapi Ny. A hanya dilakukan pembatasan cairan 1500 cc termasuk infus dan minum, dan baru mendapat terapi diuretik Furosemide $40 \mathrm{mg} / 8$ jam pada hari Sabtu, 31 Maret 2018 siang, Furosemide masuk pertama pukul 13.00 WIB. Pada pasien pertama yaitu Ny. R dilakukan implementasi pembatasan cairan dan pemberian Furosemide 40 $\mathrm{mg} / 8$ jam menghasilkan respon balance cairan yang awalnya +232 menjadi +132 pada hari pertama, balance cairan turun 100 kemudian pada hari selanjutnya tetap menggunakan terapi diuretik yang sama didapatkan hasil +22 turun 110 yang semula balance cairan +132 menjadi +22 , sedangkan pada $\mathrm{Ny}$. A hanya dilakukan pembatasan cairan menghasilkan respon yang awalnya +88 menjadi +174 , naik 86 dari semula sehingga ditambahkan intervensi terapi Furosemide $40 \mathrm{mg} / 8$ jam. Hal ini terjadi terjadi karena Ny. A mengalami sesak nafas dan produksi urin menurun yang semula $45 \mathrm{ml} / \mathrm{jam}$ menjadi
$30 \mathrm{ml} / \mathrm{jam}$ serta hasil echocardiografi menunjukkan LA LV dan RV mengalami dilatasi. Pada hari minggu dievaluasi balance cairan yang semula +174 menjadi + 32 berarti turun 142. Granero, dkk (2009) menjelaskan bahwa Furosemide adalah loop diuretic digunakan untuk mengatasi edema karena kegagalan jantung, dan hati.

Evaluasi Ny. R dilakukan pada hari Sabtu tanggal 10 Maret 2018 pukul 17.00 WIB didapatkan data subyektif pasien mengatakan bengkak di kaki berkurang dibandingkan hari kemarin, data obyektif ditemukan pitting edema kedalaman $2 \mathrm{~mm}$ kembali dalam waktu 2 detik, balance cairan : +22 , hasil assesment masalah hipervolemia teratasi sebagian dan untuk planning dilanjutkan intervensinya mencakup observasi edema, observasi adanya pembesaran hati, monitor input dan output cairan, anjurkan klien membatasi asupan cairan, kolaborasi dengan dokter dalam pemberian terapi diuretik.

Evaluasi Ny. A dilakukan pada hari Minggu tanggal 1 April 2018 pukul 20.00 WIB didapatkan data subyektif pasien mengatakan bengkak di kaki berkurang dibandingkan hari kemarin, data obyektif ditemukan edema non pitting berkurang, balance cairan : +22 , hasil assesment masalah hipervolemia teratasi sebagian dan untuk planning dilanjutkan intervensinya mencakup observasi edema, observasi adanya pembesaran hati, monitor input dan output cairan, anjurkan klien membatasi asupan cairan, kolaborasi dengan dokter dalam pemberian terapi diuretic.

\section{KESIMPULAN DAN SARAN}

Setelah dilakukan asuhan keperawatan pada Ny. R dan Ny. A 
dengan Congestive Heart Failure (CHF) di ruang ICCU RSUP dr. Soeradji Tirtonegoro Klaten peneliti membuat beberapa kesimpulan yaitu :

a. Ny. R dan Ny. A mengalami Sindrome Kardio Renal dimana terjadi penurunan fungsi ginjal ditandai dengan peningkatan kadar Ureum, BUN, dan Kreatinin.

b. Sebelum dilakukan asuhan keperawatan Ny. R mengatakan kedua kaki bengkak, pitting edema di ekstremitas bawah, $\mathrm{Ht}$ : 35,3 \%, Ureum : $\mathrm{mg} / \mathrm{dl}$, BUN : $\mathrm{mg} / \mathrm{dl}$, Creatinin : $\mathrm{mg} / \mathrm{dl}$, Balance cairan + 212, hasil foto thorak cardiomegali, pulmonary Edema. Dari data tersebut dapat ditegakkan diagnosa hipervolemia.

c. Sebelum dilakukan asuhan keperawatan Ny. A mengatakan kedua kakinya sedikit bengkak, $\mathrm{Ht}: 35,6 \%$, ureum : $68,5 \mathrm{mg} / \mathrm{dl}$, BUN : 32,0 $\mathrm{mg} / \mathrm{dl}$, creatinin : $1,68 \mathrm{mg} / \mathrm{dl}$, hasil ekokardiografi EF 32\%. Dari data tersebut dapat ditegakkan diagnosa hipervolemia.

d. Ny. R dan Ny. A setelah dilakukan asuhan keperawatan didapatkan persamaan hasil masalah hipervolemia teratasi sebagian.

e. Ada perbedaan antara $\mathrm{Ny}$. $\mathrm{R}$ dan $\mathrm{Ny}$. A setelah dilakukan asuhan keperawatan hipervolemia.

Berdasarkan hasil studi kasus yang telah dilakukan pada $\mathrm{Ny}$. $\mathrm{R}$ dan $\mathrm{Ny}$. A dengan Congestive Heart Failure (CHF) di ICCU RSUP dr. Soeradji Tirtonegoro Klaten penulis memberi saran sebagai berikut :

a. Perawat dalam menentukan intervensi mengacu pada teori

b. Perawat dalam melakukan asuhan keperawatan hendaknya selalu menjalin komunikasi terapeutik dan dokumentasikan hal yang telah dilakukan

c. Perawat pada fase evaluasi sebaiknya melakukan pengkajian ulang dan didukung dengan data subjektif dan objektif untuk menentukan tingkat keberhasilan asuhan keperawatan.

\section{DAFTAR RUJUKAN}

Granero, G.E, Longhi, Mora, Junginger, Midha, Shah, Stavchansky, Dressman, Barendes. (2009). Biowaiver Monographs for Immediate Release Solid Oral Dosage Forms: Furosemide. DOI 10.1002/jps.22030. di dapat dari https://scholar.google.co.id/scholar ?q=jurnal+keefektifan+penggunaa n+furosemide+pada+chf

Tim Pokja SDKI DPP PPNI. (2016). Standar Diagnosis Keperawatan Indonesia Definisi dan Indikator Diagnostik. Jakarta: Dewan Pengurus Pusat Persatuan Perawat Nasional Indonesia.

Udjianti, Wayan Juni. (2013). Keperawatan Kardiovaskular. Jakarta: Salemba Medika

Nursalam. (2013). Konsep dan Penerapan Metodologi Penelitian Ilmu Keperawatan. Jakarta: Salemba Medika

Muttaqin, Arif. (2009). Buku Ajar Asuhan Keperawatan Klien dengan Gangguan Sistem Kardiovaskular dan Hematologi. Jakarta: Salemba Medika

Hidayat, A. Aziz Alimul. (2014). Metode Penelitian Keperawatan dan Teknis Analisa Data. Jakarta : Salemba Medika 
Debora, Oda. (2012). Proses Keperawatan dan Pemeriksaan Fisik. Jakarta: Salemba Medika Aspiani, R. Y. (2015). Buku Ajar Asuhan Keperawatan Klien Gangguan Kardiovaskular: Aplikasi NIC \& NOC. Jakarta: EGC. 